\title{
アルカリによるペクチンの部分的脱メチル化について
}

\author{
久 保 進* . 末 光栄 充* - 別 所康 守* \\ (Susumu Kubo) (Hidemitu Suemitsu) (Yasumori Bessho)
}

\begin{abstract}
メトキシル含量 7\% 以下の low-methoxyl-pectin (以 下 L.M.P.) は酸によつて分離し得, かっ Ca のごとき 微量の多価イオンの存在で, 50\%以下の可溶性固形物に ても堅いダルを形成し，時には $1 \%$ 前後の可溶性固形物 であ良いゲルがつくられる1ので, 近時注目されている。 L.M.P. はペクチンの有する 9〜12\% のメトキシル基 を部分的に脱メチルして得られるが，その方法に䤃素 法, 酸法, アルカリ法の 3 法がある。醳素法は脱メチル が速やかで，その調節も容易であるが，製品の粘度が低 く，金属イオンに敏感で，使用に当つて硬水中の $\mathrm{Ca}$ が 完全溶解を防げる場合があり，酸法は作用髣慢であり， 高濃度の酸を使用する関倸上施設, 容器が耐酸性である ことが必要で, 設備に多額を要し，製品の粘度は高いが 金属殊にアルカリ土類金属に敏感でないので，ゲル形成 に多量の金属を要する。フルカリ法は脱メチルが速やか で調節る容易であり，製品の粘度，金属イオンに対する 感度は上記 2 法の中間である゙2) という。この実験はフ ルカリ法によるペクチンの部分的脱メチルにおける触 媒, およびその濃度, 温度, メトキシル含量と沈澱など について検討したものである。
\end{abstract}

\section{粉末ペクチン液の部分的脱メ チルについての実験}

米国産柑樀ペクチンを溶解して $1 \%$ 液 $(0.53 \%$ ペクチ ン酸), $2 \%$ 液 (1.06\% ペクチン酸)， $4 \%$ 液 $(2.12 \%$ ペ クチン酸）とし，これに $0.5 N \cdot \mathrm{NaOH}$ 液, $22 \% \mathrm{NH}_{4} \mathrm{OH}$ 水を加光て $1,3,5,7,11,17$ 時間脱メチルを行い，各時 間後一定量を $1.8 \% \mathrm{HCl}$ 液中に㩭拌し乍ら加宇, $\mathrm{pH}$ 1.4 にし, 約 15 分放置し，生でた沈筑 (L.M.P. の酸 性ゲル)を布で沪別し，沈澱を水洗してビーカーに移し， 水を加えて注意し乍ら dil $\mathrm{NaOH}$ を加光, $\mathrm{pH} 4.0$ K し,沈澱を溶解して定量にし, 浱度, メトキシル含量, 酸 性ゲルの硬さ，沈箃率などを測定した。浱度はコロイド 滴定法4)、メトキシル含量は中和法5)，沈澱率は L. M.P.

\footnotetext{
* 愛媛県立農産加工指導所（八幡浜市広瀨町） 1958年 9 月 12 日受理
}

の濃度より計算した。 $\mathrm{HCl}$ 液によつて沈澱分離出来なか つたものは試料ペクチン液をそのま測定に供した。

実臨結果 実験結果は第 1 表のごとくである。

\section{結果および考察}

（1）酸による沈澱とメトキシル含量

脱メチル作用によつてメトキシル含量が低下し，これ を酸性にすればペクチンがゲル化沈澱する。この沈澱生 成はメトキシル含量が高い間は沈澱しないが，メトキシ ル含量 5 6\% で 81\%, 4 5\% で 91\%，3〜4\% で 94\%，2〜3\% で 94\% の沈澱菜でメトキシル含量が低 くなるにしたがつて，沈澱率は高くなり，かつその沈溉 む硬くなつた。この酸による沈澱はつぎのごとくいわれ ている2。すなわちカルボキシル基の水素結合がフルב ール，あるいは水のそれよりも強くなり，故にカルボキ シル基の数が増加すると分子間相互の結合の可能性が増 してくる。小荷電の多数の集合体の生成がそれらの安定 度を下げ, 沈澱がその結果として起る。また隣接のカル ボキシル基が esterase の作用によつて遊離され，乙れ らの連鎮の部分がペクチン酸様の性質を与え, 通常酸に おける沈溊の中心として働くという報告》もある。酸に よつて起る沈澱の遷移点はてルカリによつて脱メチルさ れたペクチンはメトキシル含量 5〜6\%といわれる7が， 実験によるとぺクチンが $4 \%$ 液， $2 \%$ 液，1\% 液の時又 トキシルがそれぞれ 5.7\%，4.3\%，3.5\% で始めて沈 㵐した。メトキシル定量の測定誤差を考虑に入れると凡 そ 5 6\%，4 5\%，3〜5\% で始めて沈澱するものと考 へられ，酸による沈瑖生成の遷移点は眖メチル時のペク チン浱度によつて異り，゚クチンの濃度の高いほど高い メトキシルで沈澱するといえる。また前述のごとくメト キシルが低い注ど沈涮のゲルは硬くなつたが，同程度の メトキシルではペクチンの裖度の高いほど沈測は硬く思 われた。従つて脱メチル時のペクチンの濃度は高い湆ど よいということになる。GRAHAM ら) らによると抽出液の 場合, 0.6 1.0\% を要するという。

（2）触媒(アルカリ刘)

脱メチルに使用するアルカリとしてはアンモニフ，苛 

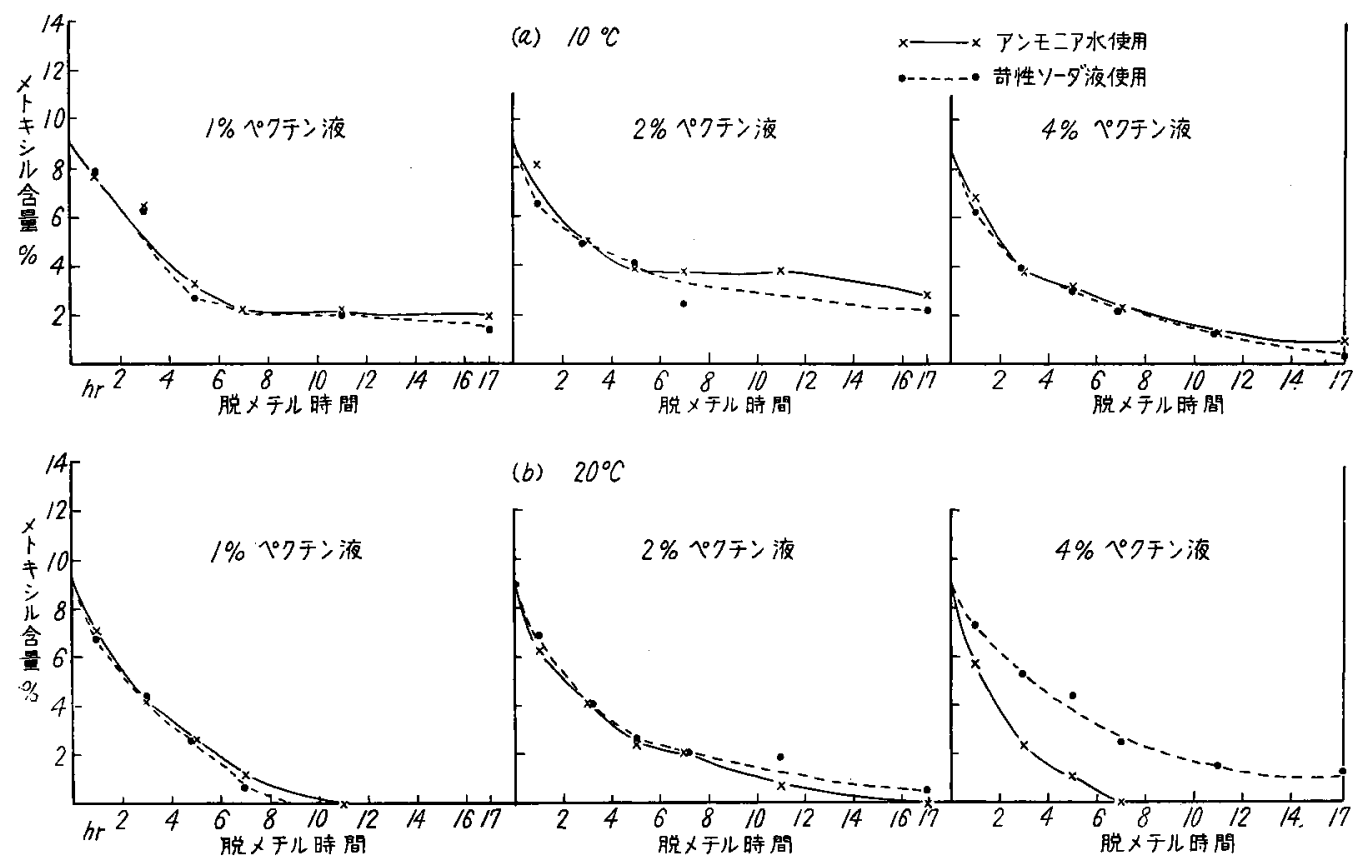

第 1 図 $\mathrm{pH}$ を調節した脱メチル作用
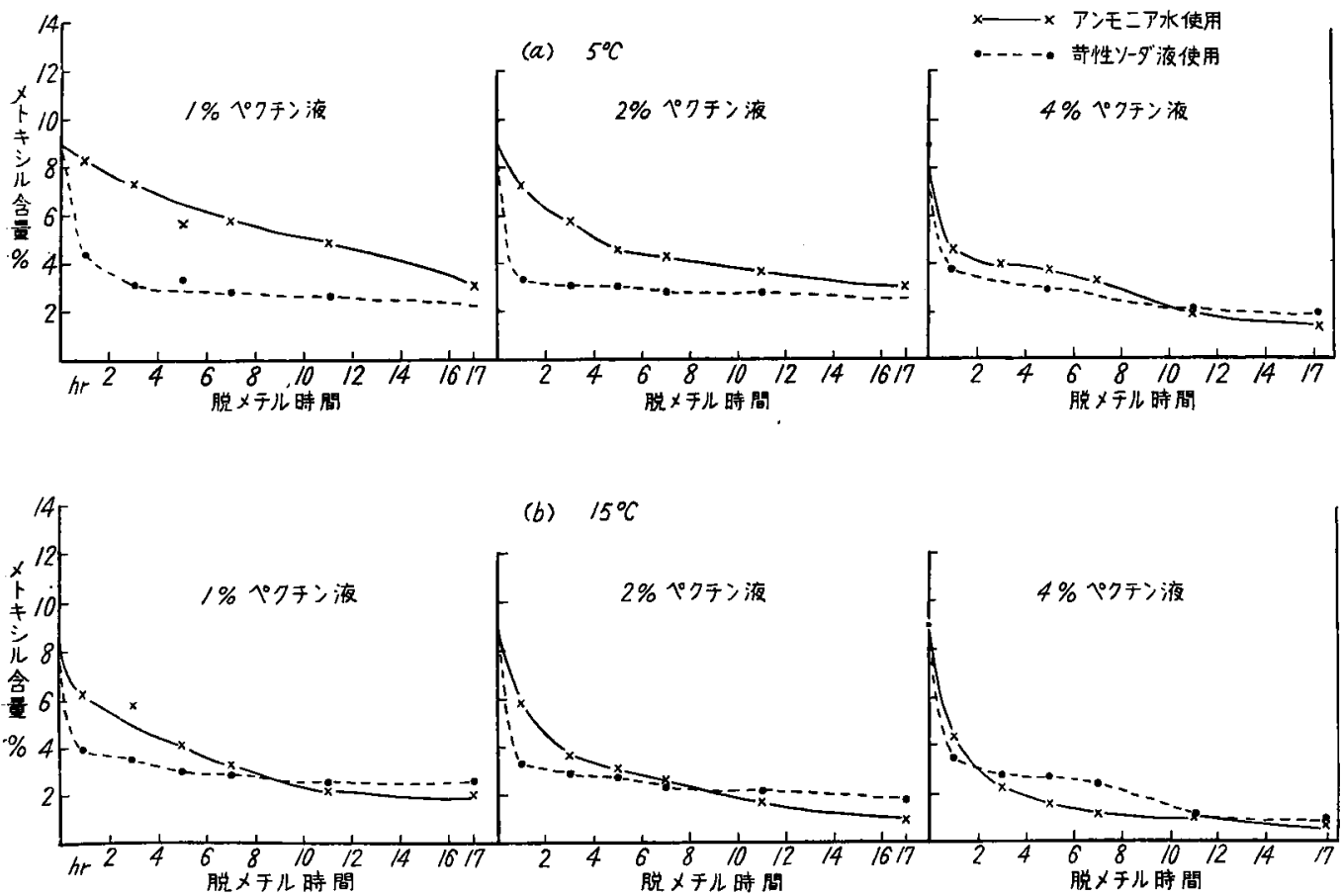

第 2 図 pH を調節しない脱メチル作用 


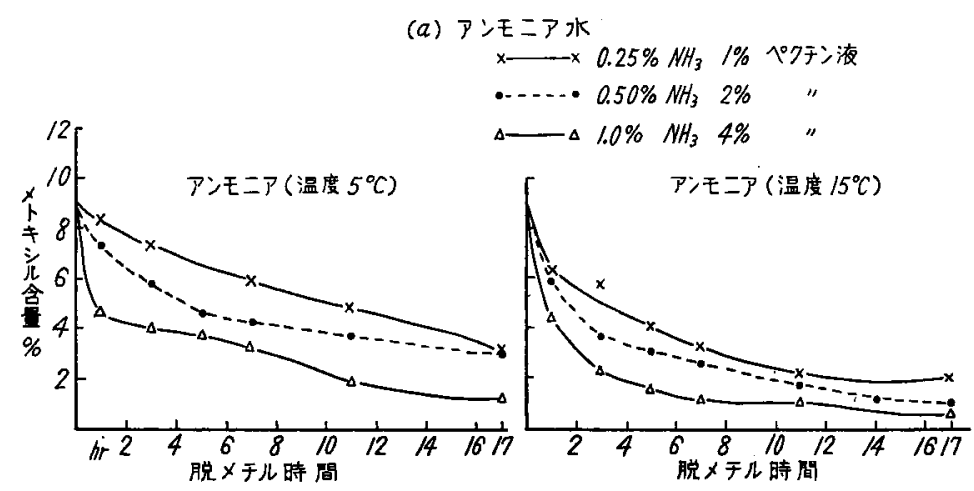

（b）苛性ソーダ
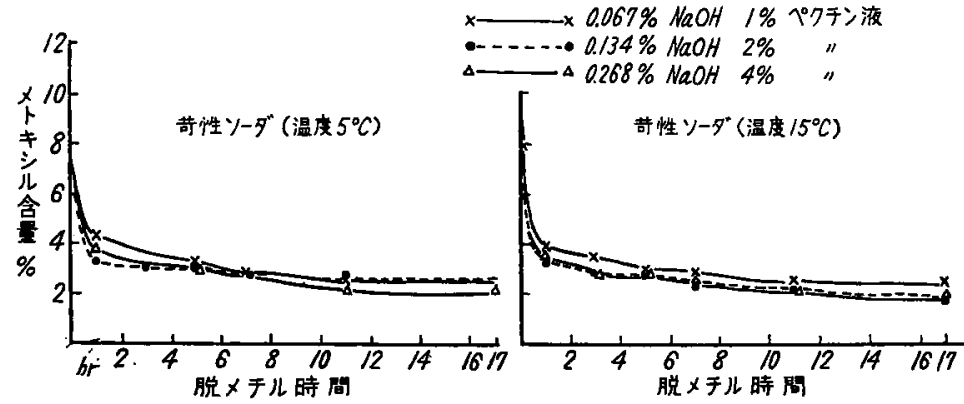

第3図フルカリの㴗度

性ソーダ，苛性カリなどが考へられるが，アンモニア， 䒬性ソーダを使用した。

(i) $\mathrm{pH}$ を 10.8〜11.0 に維持調節した場合：第 1 図 のごとく，この場合はフンモニア，苛性ソーダの間には ほとえど差異は認められない。

(ii) $\mathrm{pH}$ の維持に関係なく最初一定量添加した場合： この場合は第 2 図のごとく（i）とかなりの差異が認めら れる。アンモニアの場合は比較的ゆるやが脱メチル作 用は行われ，かつ長時間にわたつて作用が続いている が，菏性ソーダの場合は当初急激な眖メチル作用が行わ れるが，反応の進行による苛性ソーダの消費で $\mathrm{pH}$ が 低下し，以後その作用はほとえど行われない。これらの ととを考えると脱メチルは一定のアルカリの港度 $(\mathrm{pH}$ 10.8〜11.0) にならなければ，眖メチルは行われず，苛 性ソーダは作用が激しくて，その $\mathrm{pH}$ を超えれば，そ の $\mathrm{pH}$ 以下に下るまで急激な脱メチルを行うが, アン モニアはその $\mathrm{pH}$ を超えても荷性ンーダほどの激しい脱 メチルを行わず，pH の低下もゆるやかで， $\mathrm{pH}$ を維持 調節した場合と变らないことがわかる。

(3) フルカリの浱度

$\mathrm{pH}$ を調節維持しない場合はフルカリの浱度が問題に
なるが，第 3 図はその場合の結果である。この場合ぺク チンの濃度を一定にせず，フルカリの濃度と比例して濃 くしているので, フルカリの濃度による差異はやや瞹眜 なるのになつてくるが, フンモニての場合は明確に差異 があり，ペクチンの浱度よりむアンモニアの浱度の影響 の大きいことがうかがえる。脱メルチ作用は温度の影響 を受け，酸によつて沈搌する L.M.P. はペクチンの濃 度によつて異るので，一概には云えないが，商業的に有 用な L. M.P. はメトキシル 2〜5\% といわれる8 の で，この範囲のメトキシル含量にするには，15C では フンモニフ $0.25 \%$ 濃度では 3〜12 時間 (1\% ペクチ ン液), $0.5 \%$ では 2〜10 時間 (2\% ペクチン液), 1.0\% では 1〜4時間（4\%ペクチン液）で，フンモ= フの裖度が高いほど短時間ですむが，しかしてンモニア の濃度它高くすることは他の点も考虑せねばならぬ。す なわちてンモニフ 0.5\% にするには 22〜24\% のアン モニア水であれば，少くともアンモニア水をペクチン液 の $2 \%$ 容量以上に使用する必要があり，抽出液の脱丈 チルに当つてはかなりのアンモニア水を要し，経斉的の 面からも検討する必要加ある。しかし $5{ }^{\circ} \mathrm{C}$ とではフン モニア $0.25 \%$ では 10 時間以上を要し, 品質および操 


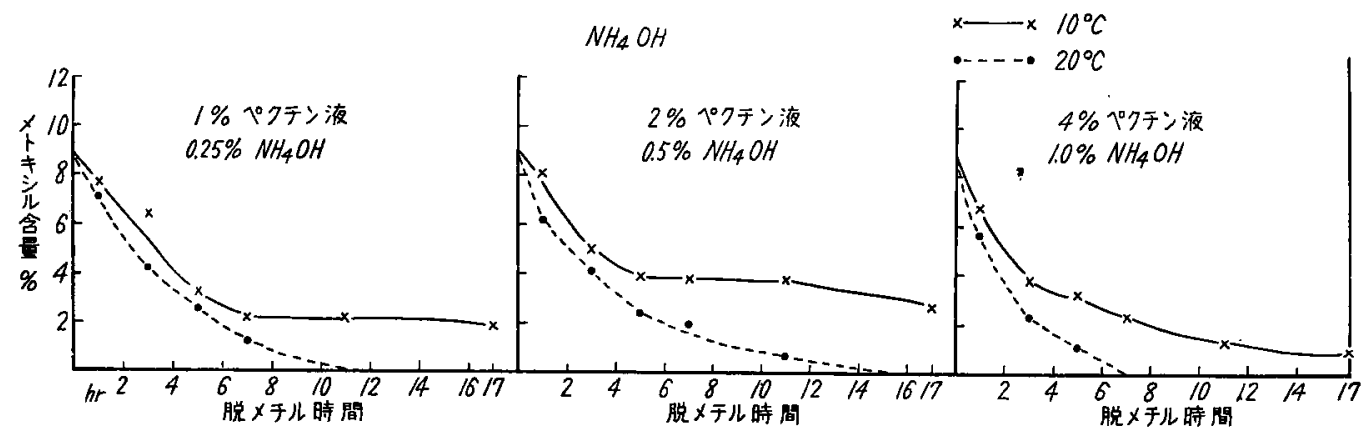

$\mathrm{NaOH}$

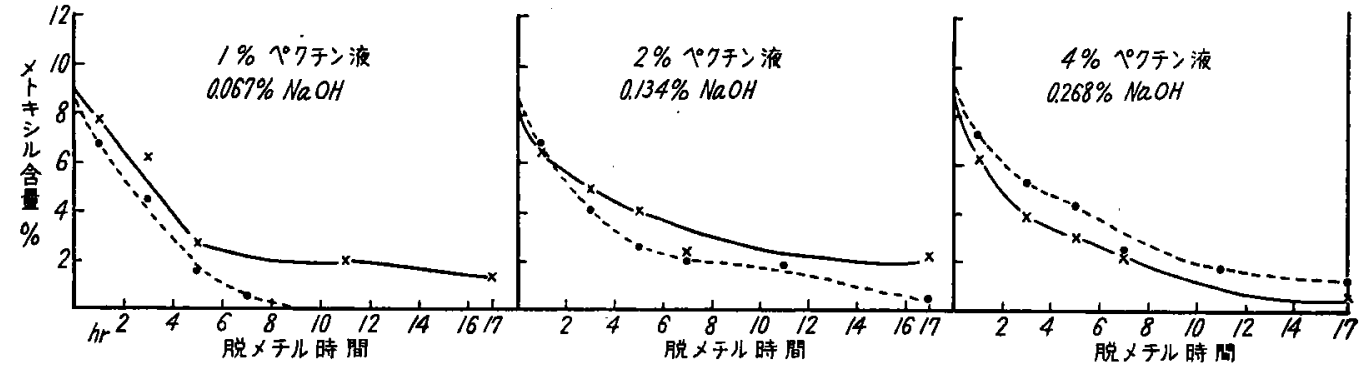

第 4 図温度による相異

(pHを調節した場合)
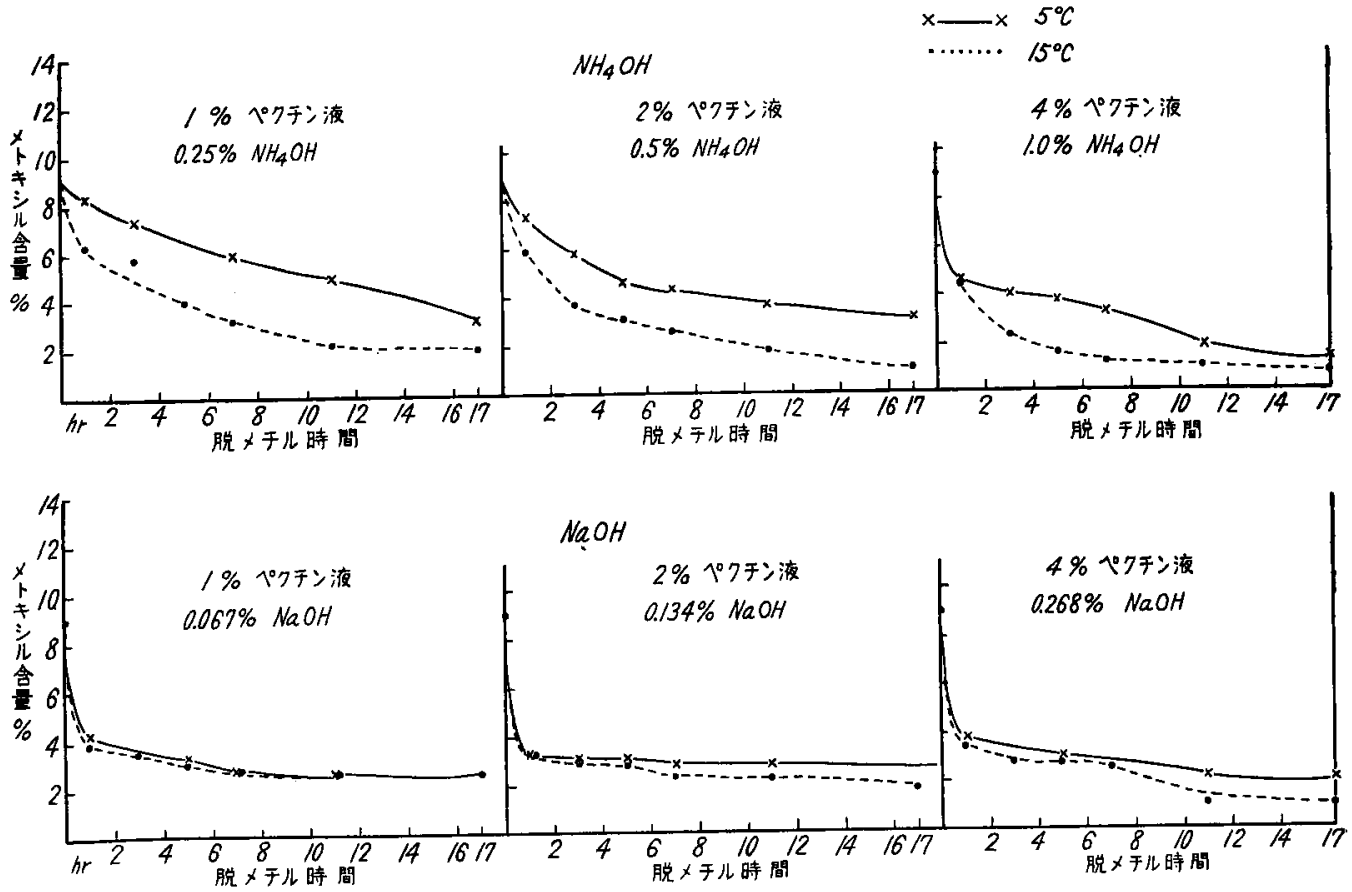

第 5 図温度による相異

（pH を調節せず当初一定量のフルカリを加えた場合） 
作上適当でないと思われる。一方苛性ソーダは濃度, 温 度による差異は認め難いが，前記のごとく反応当初激し すぎて $\mathrm{pH}$ 調節せずに行うには適当でない。

(4) 温 度

温度の影響は $\mathrm{pH}$ を調節した場合, しからざる埸合, アンモニア, 苛性ソーダの場合によつてやや異るようて あるが，最初一定量の菏性ソーダを加え， pH の調節し なかつた場合を除いて，いずれも温度によつて促進され る。脱メチルの温度はつぎの酸性ゲル沈澱生成時の温度 に影響し，沈澱率は温度上昇によつて低下し ${ }^{21}$ ，また高 温はペクチンの劣化を伴うので，低温程良いが時間が長 くなる。これはアルカリの浱度と関連するわけで，時間 の許す限り温度, およびフルカリの䟴度は低いほど良 W。

(5) 特 間

脱メチル時間は操作の上からは短時間であることが望 ましいが，そのためには温度あるいはフルカリの濃度を 増す必要があり，その結果種々好ましくないことを惹起
するので, 脱メチル時間はアルカリの濃度, 温度, メト キシル含量の3者によつて定めねばならぬ。

(6)メトキシル含量

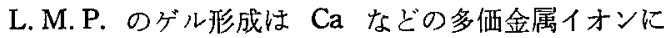
よるイオン結合によるもので，メトキシル含量が低くな るほどこれら金属に対して敏感となり，ゲル形成の金属 量は少くてすむことになるが，メトキシル含量の余りに 低いものは，粘弾性の均一ゲルがえられなかつた。この 限界は判然としなかつたが，2\% 前後ではないかと思わ れた。したがつて用途によつて異つてくると思われるけ れど,メトキシル含量が低く過ぎにならないよう注意す ることが肝要である。

\section{抽出液の部分的脱メチル}

温州外皮抽出液について予䚚的に部分的脱メチルを行 つたところ，5.0\% 以下のメトキシル含量にするに長 時間かかつた。
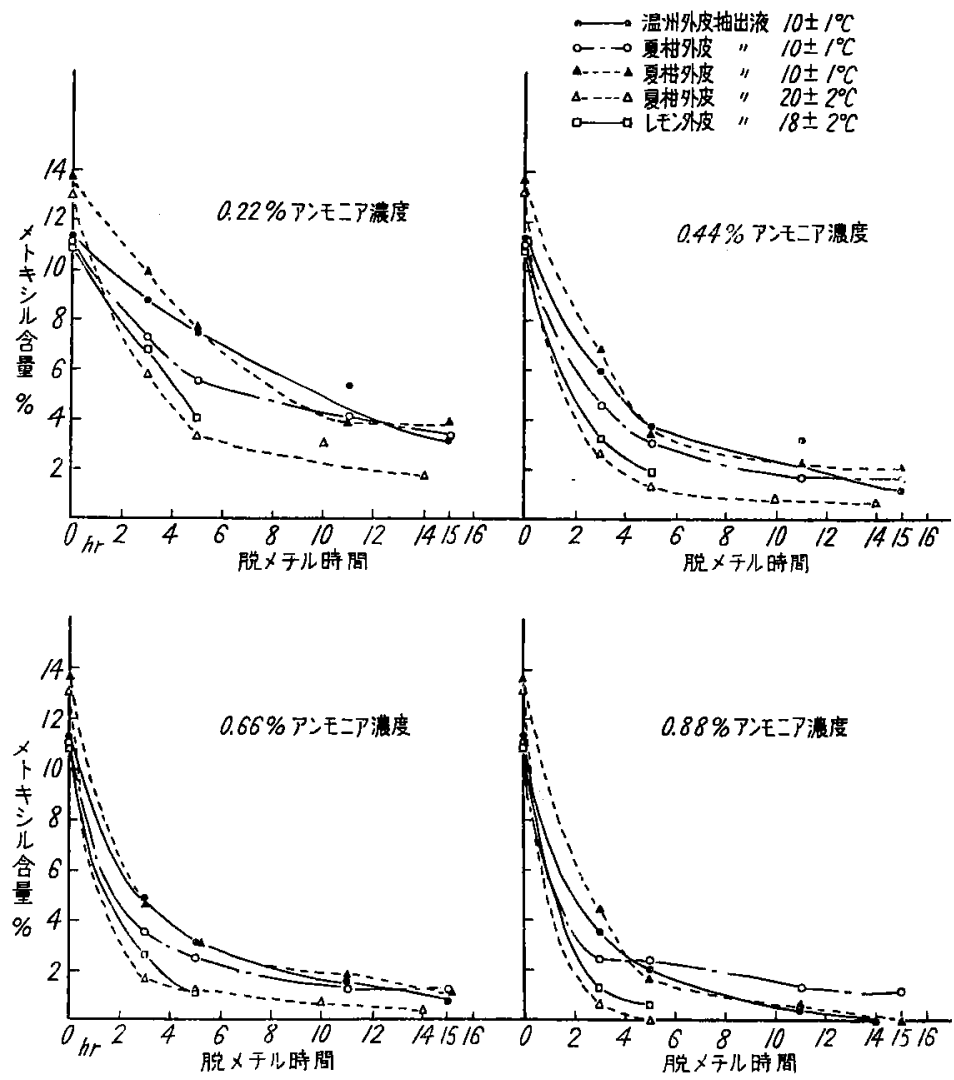

第 6 図抽出液の脱メチル 


\begin{tabular}{|c|c|c|c|}
\hline $\begin{array}{l}\text { 脱メチル } \\
\text { 時 } \\
\mathrm{hr}\end{array}$ & $\begin{array}{c}\text { フモモ } \\
7 \text { 添加量 } \\
\text { ml }\end{array}$ & $\begin{array}{l}\text { メトキシ } \\
\text { ル含 量 } \\
\text { \% }\end{array}$ & $\begin{array}{l}\text { 酸性ゲル } \\
\text { の沈 澱 }\end{array}$ \\
\hline $\begin{array}{r}0 \\
12 \\
14 \\
20 \\
36\end{array}$ & $\begin{array}{r}13 \\
0 \\
3 \\
0 \\
0\end{array}$ & $\begin{array}{l}7.0 \\
5.5 \\
3.5\end{array}$ & $\begin{array}{l}- \\
+ \\
+\end{array}$ \\
\hline
\end{tabular}

(注) べクチン酸 $0.46 \%$, メトシル $10.8 \%$ の抽出 液を $1 / 2$ 量に濃縮したるの。一は沈澱せず，十 は沈筑の硬さの度合。

フンモニア水の添加は抽出液 $1,000 \mathrm{~m} l$ K対し, $16 \mathrm{ml}$ で 1.6\% 容量の使用であるが, このくらいのアンモニア 水の添加では時間が長すぎて実際的でない。この場合て ンモニア水の添加量を多くし，フンモニアの濃度を高く すれば，時間は短かくなるが，アンモニア水の多量の使 用は前述のごとく，経阁的に問題があるから，抽出液の 中和に消費されるアンモニて炭節約するために，抽出液 の $\mathrm{pH}$ を $0.1 \mathrm{~N}-\mathrm{NaOH}$ 液で尒め 6.0〜6.5 亿調節し, 几かる後脱メチルを行つた。これによると（第 6 図） $10^{2} \mathrm{C}$ においてはアンモ二ア水 $1 \%$ 容量添加(濃度 $0.22 \%$ アンモニア) ではメトキシル含量 5〜2\% にするには大 凡そ 6 12 時間究要し，操作上やや長過 ぎる。 $2 \%$ $(0.44 \%), 3 \%(0.66 \%), 4 \%(0.88 \%)$ 容量添加でそ れぞれ約 3〜11 時間, 2〜8 時間, 1〜5 時間であつた。 $0.88 \%$ (4\% 容量添加) の涨度では脱メチルが急激で調 節に難しいのではないかと考へられ，0.6\% 程度（約 $3 \%$ 容量添加）の濃度で行うが適当と思われるが，かな りのアンモニア水要するわけである。

温度が $20^{\circ} \mathrm{C}$ の場合は $1 \%, 2 \%, 3 \%, 4 \%$ 容量添加 で，それぞれ 3〜10，1〜4，1〜3，1〜2 時間で 1\% 容 量の添加でもほぼ操作上満足できる時間となる。脱メチ ル温度によるペクチンの品質上の相異は検討しなかつた ので, $20^{\circ} \mathrm{C}, 1 \%$ 容量の添加 $(0.22 \%$ フンモニて） で 退いとは断言できないが，少くともフンモ二フ水節減の 観点からすると必然的に温度を上げて行うことが必要と なる。

\section{結 論}

粉末ペクチン液，柑菕外皮抽出液について部分的脱メ
チルを行い, 温度, フルカリの濃度, 時間およびメトキ シル含量の間の関係およびつぎのことを知つた。

(1) 脱メチルに際してはペクチンの浱度が高いほど 良以。

（2） L. M. P. はメトキシル含量によつて異るが，脱 メチル前ペクチンの約 $90 \%$ 沈澱する。

(3) フンモニフは反応が緩慢で， $10 \sim 15^{\circ} \mathrm{C} ， 0.9 \%$ 以下の浱度では $\mathrm{pH}$ 它調節せずに行うも, 調節して行 うも大差なく, 部分的脱メチルのアルカリ剂としてはて ンモニアの方が良い。

（4）部分的脱メチルの最適条件を定めることは難し く，かつ終末点のメトキシル含量を直ちに知ることがで きないので，予め実施条件下で脱メチル究行い，反応状 態を知つて持くことが必要である。

（5）抽出液の $\mathrm{pH}$ のまま, アンモニア水を加え, 脱メチルするにはアンモニア水の多量を要するので, 脱 メチル直前に $\mathrm{pH}$ を 6.0 前後に調節してアンモニア水 を加えるのが良いのではないかと思う。

最後に御校閲頂いた食研, 塭入部長に厚く御礼申乙上 げます。

$$
\text { 文献 }
$$

1) Z. I. Kertesz: The Pectic Substance, 511 (1951).

2) R. M. McCready, H. S. Owens, A. D. Shepherd \& W. D. MA.laY: Ind. Eng. Chem., 38, 1254 (1946).

3) G. H. Joseph, A. H. Kieser \& E. F. Bryant: Food Technol., 3, 85 (1949).

4) S. Okimasu: Bull. Agr. Chem. Soc. Japan, 20, 29 (1956).

5) C. L. Hinton: Fruits Pectins, Their Chemical Behaviour and Chemical Properties, 33 (1940).

6) R. P. Graham, A. D. Shepherd: J. Agr. Food. Chem., 1, 993 (1953).

7) T. H. Schultz, H. Lotzkar, H. S. Owens \& W. D. Maclay: J. Phys. Chem., 49, 554 (1945).

8) H. S. Owens \& H. Lotzkar: U. S. Pat., 2,522, 534 (1950). 